\title{
Austerity policies in Brazil may affect violence related outcomes
}

\author{
Políticas de austeridade no Brasil podem afetar os desfechos \\ relacionados à violência
}

Daiane Borges Machado (https://orcid.org/0000-0003-2959-4650) 1,2

Julia Moreira Pescarini (https://orcid.org/0000-0001-8711-9589) ${ }^{1}$

Luís Fernando Silva Castro de Araújo (https://orcid.org/0000-0002-0952-5052) 1,3

Maurício Lima Barreto (https://orcid.org/0000-0002-0215-4930) 1,4

\footnotetext{
${ }^{1}$ Centro de Integração de Dados e Conhecimentos para Saúde (CIDACS). R. Mundo 121, Trobogy. 41745-715 Salvador BA Brasil.

daianedbm@hotmail.com ${ }^{2}$ Centre for Global Mental Health - LSHTM. Londres Inglaterra.

${ }^{3}$ Department of Psychiatry, University of Melbourne.

Victoria Austrália.

${ }^{4}$ Instituto de Saúde Coletiva, Universidade Federal da Bahia. Salvador BA Brasil.
}

\begin{abstract}
Economic crisis is often managed with austerity policies. These measures seem to burden the population disproportionately, with the poorer being more affected. This paper aims to investigate health outcomes performance after the recent Brazilian crisis and gauge whether that pattern also emerged. Public domain data from 2010 to 2017 was used, and it was found that suicide and homicide rates increased after 2014, while mortality by road traffic injuries decreased at the same time. Furthermore, these trends were exacerbated in the North and Northeast regions and in the municipalities with the poorest quintiles of $\mathrm{Hu}$ man Development Index (HDI). The austerity policies followed by the Brazilian economic crisis may have influenced the mortality trends due to external causes, with a possible stronger impact in the North and Northeast regions and among less developed municipalities.
\end{abstract}

Key words Austerity, Mortality, Suicide, Homicide, Road traffic injuries.
Resumo Crises econômicas são comumente administradas com politicas de austeridade. Estas medidas atingem a população de modo desproporcional, sendo os mais pobres os mais afetados. Este artigo pretende investigar a performance dos desfechos de saúde após a crise econômica recente e avaliar se o padrão de desproporcionalidade também ocorreu no Brasil. Dados públicos de 2010 a 2017 foram utilizados e encontramos que suicídios e taxas de homicídios aumentaram depois de 2014, enquanto mortalidade por acidentes de trânsito diminuíram. Além disto, estas tendências foram exacerbadas no Norte e no Nordeste e em municípios no quintil mais pobre em termos de Indice de Desenvolvimento Humano (IDH). As políticas de austeridade que se seguiram à crise econômica brasileira podem ter influenciado a tendência de mortalidade por causas externas, com um possivel maior impacto no Norte e no Nordeste e em municípios menos desenvolvidos. Palavras-chave Austeridade, Mortalidade, Suicídio, Homicídio, Acidentes no trânsito. 


\section{Introduction}

The Brazilian economic crisis from 2014 led to a series of budget cutting policies from the government ${ }^{1}$. Financial crises occur when assets lose value, hindering other economy agents' ability to paying debts. In modern economies, this is often followed by policies that attempt to reduce ex-penditure, hoping for an ensuing debt reduction. The effects of austerity type of management of crisis are known to burden the poor disproportionately ${ }^{2,3}$. This burden can become explicit in health outcomes, as has been shown for the economic crisis in Europe ${ }^{4}$, it is only now that consequences for Brazilians can be gauged ${ }^{5}$.

In the past two decades, Brazil improved economically and in terms of health conditions. There were significant decreases in child mortality ${ }^{5}$ especially in mortality related to socioeconomic situation as child mortality by diarrhea ${ }^{6}$. However, since 2015 these indicators seem not to present the same performance ${ }^{6,7}$. A recent study showed that the implementation of fiscal austerity measures could contribute to increasing the number of preventable child deaths and hospitalisations in Brazil. According to the authors, the current economic crisis together with the package of austerity measures may jeopardise the gains Brazilian government had made in poverty reduction and improvements in health outcomes, especially among poor Brazilians ${ }^{6}$.

Mortality by external causes could also be influenced by austerity measures. We have recently reported the income inequality effect on suicide rate in $\mathrm{Brazil}^{8}$ that made clear the association between the Gini index and suicidal behavior. We have also recently shown that suicide and homicides rates are affected by the Brazilian social protection programme, the Brazilian conditional cash transfer program (Bolsa Família) were associated with decreased suicide and homicide rates in the Brazilian municipalities ${ }^{9,10}$. Since it has been suggested that severe economic crisis may increase socioeconomic inequality ${ }^{11}$, and hinders social protection nets, as was the case with the recent crisis in Greece, one should expect some health outcomes to worsen following recessions.

For this reason, we set out to examine the trends in homicide and suicide rates before and after the start of the austerity policies in Brazil in the year 2015. We also analysed trends in mortality rate from road traffic injuries after the economic crisis has deepened from 2014 as a comparison. Our hypothesis is that these outcomes worsened, following what happened in many other countries which have gone through a recession recently.

\section{Methods}

We evaluated the trends of mortality by suicide, homicide and by road traffic injuries per 100,000 inhabitants for each municipality in Brazil, from 2010 to 2017.

\section{Data sources}

Mortality data were collected from the Brazilian Ministry of Health's Mortality Information System available at DATASUS (http://datasus. saude.gov.br/). Socioeconomic and demographic variables were obtained from the Brazilian Institute of Geography and Statistics (http://www. ibge.gov.br/home). All data sources are fully available online.

\section{Outcomes and variables definitions}

Austerity measures are known for influencing outcomes in health associated with income and poverty. Little is known however, about the association between austerity measures and deaths due to external causes, especially suicide and homicide that have both been previously associated with income in Brazil ${ }^{8-10}$. We analysed these two outcomes (suicide and homicide), as well as road traffic injuries as it is well known that this is an important health outcome that tends to decreases in periods of economic crisis.

We used the International Classification of Diseases, 10th revision (ICD-10) $)^{12}$ to analyse trends in mortality by external causes including those resulted from suicide, which is defined as death resulted from the action of intentionally causing one's own death (ICD-10 X60-X84); homicides, which is defined as a death resulting from injuries inflicted by another person with intent to injure or kill using any means (ICD10: X85-Y09) and road traffic injuries (ICD-10: V01-V99).

\section{Statistical Analyses}

We performed a descriptive analysis of the mortality trends in Brazil by each type of outcome and stratified by Brazilian region and yearly quintile of Human Development Index (HDI). All mortality data by specific causes were age standardized. 


\section{Results}

Figure 1 shows the trends in suicide rate, homicide rate and death by road traffic injuries from 2010 to 2017, overall and by Brazilian region. It shows the same mortality trends (suicide rate, homicide rate and death by road traffic injuries) by quintile of municipal HDI.

Overall standardized rates of suicide and homicide increased from 2014, while mortality by road traffic injuries steady decreased from 2014 (Figure 1).

Analysing by municipal quintile of HDI, the municipalities in the lowest quintile had the highest increase in suicide and homicide (Figure 2). While mortality due to road traffic injuries had the highest decrease in the municipalities in the highest quintile of HDI (Figure 2).

Suicide standardized rates increased by $10 \%$ from 2010 to 2014 and by $11 \%$ from 2014 to 2017, while standardized mortality by road traffic injuries decreased by $0.7 \%$ from 2010 to 2014 and by $22 \%$ from 2014 to 2017 . The highest suicide rate increase (from 2014 to 2017) occurred in the North, Northeast and South, 22\%, 17\% and 18\% respectively. For homicide, in the same period, the highest increase also occurred in the North and Northeast, $27 \%$ and $13 \%$ respectively (Table 1). The richest region of Brazil had no increase in suicide rates and had the highest decreases in homicide $(-15 \%)$ and in mortality by road traffic injuries (-27\%), from 2014 to 2017 (Table 1).

The difference in the mortality trends were supported by the coefficients of binomial regression for the two periods, before (2010-2014) and after (2014-2017) the Brazilian economic crisis and related austerity, measures have started (Table 2). Suicide increased in all regions in the second period, except in the Southeast, where there was a slightly decrease. For homicide rates, there was an increase after 2014 in the North, Northeast and in the South and a decrease in the Southeast and Central-West. While mortality rates of road traffic injuries had a decreasing trend after 2014, for all the Brazilian regions and the highest decrease in the Southeast and Central-West regions.

\section{Discussion}

Health status is related to social, economic and environmental conditions, such as basic sanitation, housing, work, education and income ${ }^{7}$. Therefore, economic austerity policies are expected to impact on health related outcomes. In our study, we found an increasing of suicide and homicide rates after the crisis and austerity policies have started in Brazil. On the other hand, the mortality rate from road traffic injuries has significantly decreased in the same period, from 2014 to 2017.

In Brazil, since 2014, economic crisis led to increasing unemployment, mainly in low-income populations, and the poverty rate (those with an income of less than US $\$ 43$ a month) has increased from $7.4 \%$ in 2014 to $8.7 \%$ in 2015 . The extreme poverty rate (those with an income of less than US $\$ 21$ a month) also increased from $2.8 \%$ to $3.4 \%$ in the same period ${ }^{6}$.

Mortality by external causes can be quite sensitive to socioeconomic changes, especially when austerity policies are put in place in a moment when populations most needed social protection. Recession results in decreased consumption and decreased access to goods; austerity exarcebates this process. Economic crisis and austerity policies also increase stress related to socioeconomic hardship, which might lead to family disruption, alcohol abuse and hopelessness.

\section{Suicide}

In Brazil, suicide rates are not as high as it is in the rest of the world. Although suicide in Brazil is experiencing growth, for example, it was reported an increase of $20 \%$ from 1980 to $2000^{13}$ and of $28,6 \%$ from 2000 to $2012^{14}$. Brazil follows the worldwide pattern in terms of gender: males are more likely to become a victim of suicide, whereas females generally have more attempts ${ }^{13}$. In 2012, Brazil had a general suicide rate of 6,4 per 100,000 inhabitants and of 2,7 per 100,000 inhabitants among women and of 10 per 100,000 inhabitants among men.

Suicide is a complex phenomenon, besides the biological factors, life events also seem to be related to its occurrence. There is increasing literature showing that socioeconomic hardship increases suicide risk in Brazil ${ }^{8,9}$. Studies have shown its association with income, income inequality and coverage of the Brazilian cash transfer programme $e^{8,9}$, while the Brazilian mental health programme, as currently organized, has 

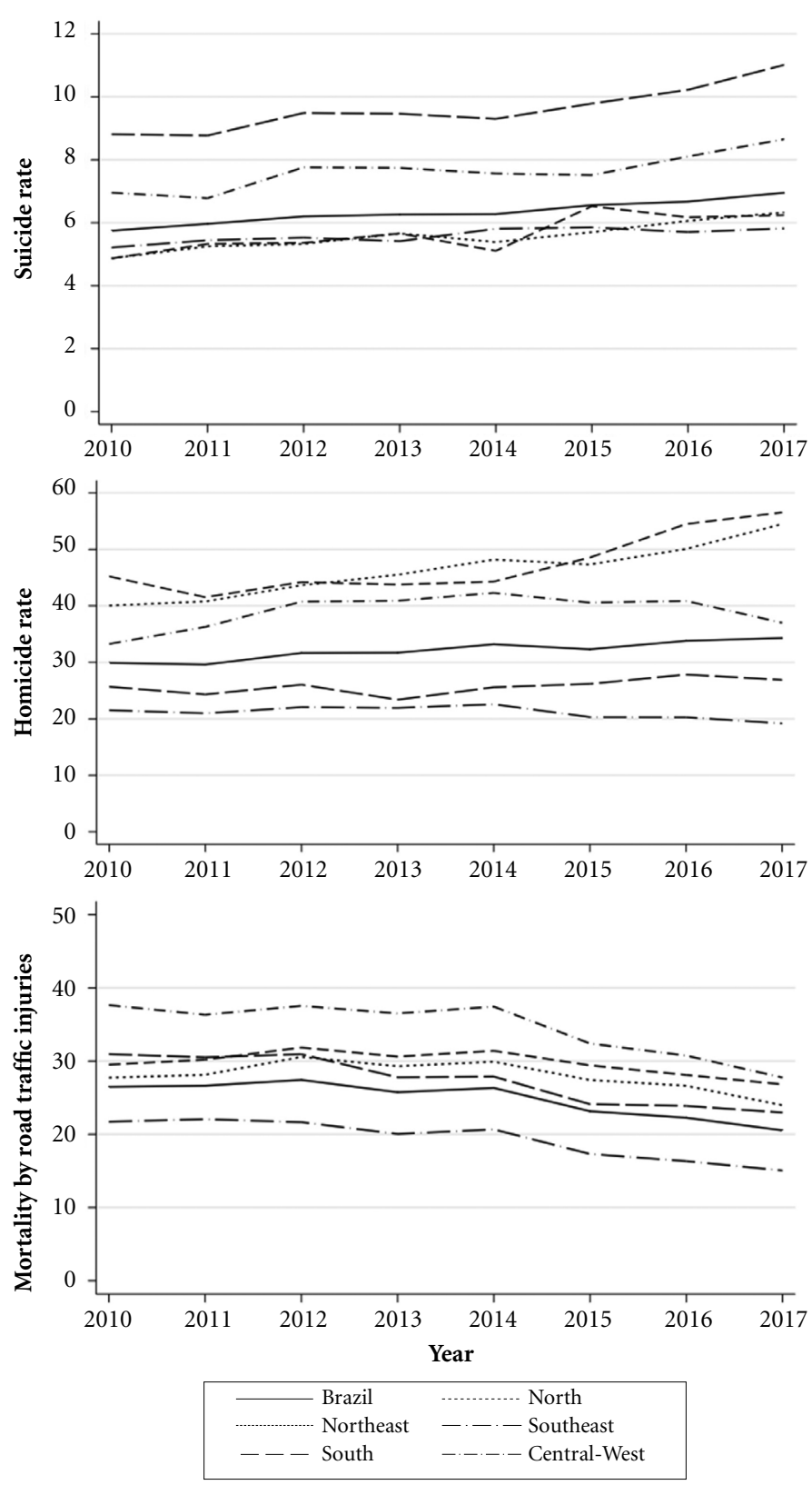

Figure 1. Suicide rates, homicide rates and mortality by road traffic injuries, per 100,000 individuals in Brazil and Brazilian regions.

not been associated with decreased suicide ${ }^{15}$. It may happen because economic hardship might affect many aspects of people life, as previously mentioned, it limits the consumption power and access to goodness. Even if we have assumed suicide be exclusively related to mental health problems, the limited budget together with austerity policies in the health assistance could prevent people from having access to mental health treatments and therefore, increase the chances of becoming a victim of suicide.

Our data complement these reports. The poorest regions, North and Northeast have shown the highest increases in the suicide standardized rates from 2010 to $2017,28 \%$ and $29 \%$ respectively. However, the increasing trend found 

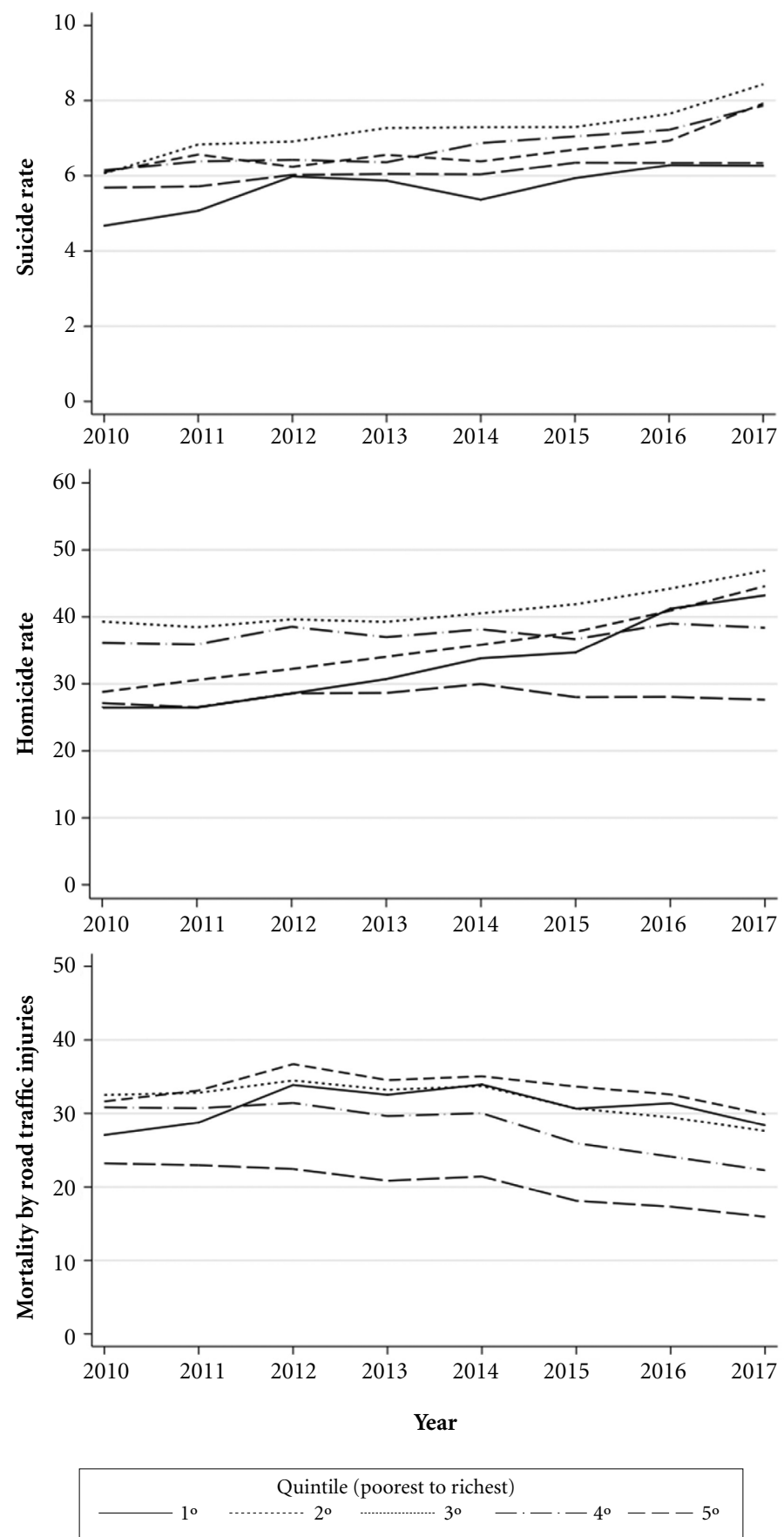

Figure 2. Suicide rates, homicide rates and mortality by road traffic injuries according to municipality quintile of HDI.

in our analysis may reflect the four years recession that started in 2014, as the increase from 2010 to 2014 was $4.9 \%$ in the North and $10.5 \%$ in the Northeast, while the increase from 2014 to 2017 was $22 \%$ in the North and $17 \%$ in the Northeast. The relationship between recession and risk of suicide has been well documented before, from the foreclosure crisis in $\mathrm{US}^{16}$ to more recent cri- 
Table 1. Standardized suicide rates, homicide rates and mortality by road traffic injuries (RTI), overall and by Brazilian regions, from 2010 to 2017 .

\begin{tabular}{|c|c|c|c|}
\hline & $\begin{array}{c}\text { Suicide rate } \\
/ 100000\end{array}$ & $\begin{array}{c}\text { Homicide } \\
\text { rate } / 100000\end{array}$ & $\begin{array}{l}\text { Mortality by } \\
\text { RTI / } 100000\end{array}$ \\
\hline \multicolumn{4}{|l|}{ Brazil } \\
\hline 2010 & 5.7 & 29.9 & 26.5 \\
\hline 2011 & 6.0 & 29.6 & 26.6 \\
\hline 2012 & 6.2 & 31.7 & 27.4 \\
\hline 2013 & 6.3 & 31.7 & 25.7 \\
\hline 2014 & 6.3 & 33.2 & 26.3 \\
\hline 2015 & 6.6 & 32.3 & 23.1 \\
\hline 2016 & 6.7 & 33.8 & 22.3 \\
\hline 2017 & 7.0 & 34.3 & 20.5 \\
\hline \multicolumn{4}{|l|}{ North } \\
\hline 2010 & 4.9 & 45.2 & 29.5 \\
\hline 2011 & 5.3 & 41.5 & 30.2 \\
\hline 2012 & 5.4 & 44.2 & 31.8 \\
\hline 2013 & 5.7 & 43.8 & 30.6 \\
\hline 2014 & 5.1 & 44.3 & 31.4 \\
\hline 2015 & 6.5 & 48.5 & 29.4 \\
\hline 2016 & 6.2 & 54.5 & 28.1 \\
\hline 2017 & 6.2 & 56.5 & 26.8 \\
\hline \multicolumn{4}{|c|}{ Northeast } \\
\hline 2010 & 4.9 & 40.0 & 27.7 \\
\hline 2011 & 5.2 & 40.8 & 28.1 \\
\hline 2012 & 5.3 & 43.6 & 30.6 \\
\hline 2013 & 5.7 & 45.5 & 29.3 \\
\hline 2014 & 5.4 & 48.2 & 29.9 \\
\hline 2015 & 5.7 & 47.3 & 27.4 \\
\hline 2016 & 6.1 & 50.1 & 26.6 \\
\hline 2017 & 6.3 & 54.5 & 24.0 \\
\hline \multicolumn{4}{|c|}{ Southeast } \\
\hline 2010 & 5.2 & 21.5 & 21.7 \\
\hline 2011 & 5.4 & 21.0 & 22.1 \\
\hline 2012 & 5.5 & 22.1 & 21.7 \\
\hline 2013 & 5.4 & 21.9 & 20.0 \\
\hline 2014 & 5.8 & 22.6 & 20.7 \\
\hline 2015 & 5.8 & 20.3 & 17.3 \\
\hline 2016 & 5.7 & 20.3 & 16.3 \\
\hline 2017 & 5.8 & 19.2 & 15.0 \\
\hline \multicolumn{4}{|l|}{ South } \\
\hline 2010 & 8.8 & 25.7 & 30.9 \\
\hline 2011 & 8.8 & 24.3 & 30.5 \\
\hline 2012 & 9.5 & 26.0 & 30.9 \\
\hline 2013 & 9.5 & 23.4 & 27.8 \\
\hline 2014 & 9.3 & 25.6 & 27.9 \\
\hline 2015 & 9.8 & 26.2 & 24.1 \\
\hline 2016 & 10.2 & 27.8 & 23.9 \\
\hline 2017 & 11.0 & 26.9 & 23.0 \\
\hline \multicolumn{4}{|c|}{ Central-West } \\
\hline 2010 & 7.0 & 33.3 & 37.6 \\
\hline 2011 & 6.8 & 36.3 & 36.3 \\
\hline 2012 & 7.8 & 40.7 & 37.5 \\
\hline 2013 & 7.7 & 40.9 & 36.5 \\
\hline 2014 & 7.6 & 42.3 & 37.4 \\
\hline 2015 & 7.5 & 40.6 & 32.4 \\
\hline 2016 & 8.1 & 40.9 & 30.7 \\
\hline 2017 & 8.7 & 37.0 & 27.7 \\
\hline
\end{tabular}

sis in Japan ${ }^{17}$, Spain ${ }^{18}$ and in Greece ${ }^{19}$ and might happen when socioeconomic programmes are not put in place to mitigate the effect of the crisis.

\section{Homicide}

Brazil has the unfortunate notoriety of being one of the most violent countries. In 2016, for example, there were 30.3 deaths per 100 thousand inhabitants according to the Violence Atlas, a publication from the Institute for Applied Economic Research (IPEA) ${ }^{20}$. As per latest IPEA report, there is an important variation of violent deaths within Brazilian states, as there was an increase of $257 \%$ of violent deaths in the state of Rio Grande do Norte in the last decade, but a decrease of $57 \%$ in the state of São Paulo for the same period ${ }^{20}$.

The young adults are the most frequently victimized. According to the same report from 2018 , violent deaths amount to $56.5 \%$ of death causes among young people, from 15 to 19 years old in Brazil. The homicide rate among non-African Americans decreased by $6.8 \%$, whereas the African Americans death by homicide has raised $23 \%^{21}$. The wide availability of firearms seems to be an important factor for the high homicide rate in Brazil. Deaths by firearms have consistently increased in a staggering rate of $6.2 \%$ per year from 1980 to 2003 (accounting for population growth) when it stabilized until 2014 following a disarming campaign that was put in place in Brazil in $2004^{22}$.

Globally the homicide rate is 6.7 per 100 000 inhabitants per year; in low-middle-income American countries is 28.5 per 100 000, the highest rate worldwide ${ }^{23}$. Our findings confirm what is known about the homicide rates in Brazil, it is very high across the country as all country regions are placed above the world mean rates. However, our study shows a difference in the regions' trend from 2010 to 2017.

In the current paper, we reported a $14.7 \%$ increase in the standardized Brazilian homicide rate from 2010 to 2017 . However, a statically significant higher increase in the North $(25 \%)$ and in the Northeast $(36 \%)$ while it decreased in the Southeast (11\% decrease).

We also compared 2010 to 2014 and 2014 to 2017 and found that the growth for the first period was $3 \%$ and $0.7 \%$ for the second, both differences were significant. Therefore, the overall national rate is slowing down, but with great inequality. The statistically significant decrease of $5.8 \%$ in the Southeast region and the $3.9 \%$ de- 
Table 2. Coefficients ${ }^{1}$ for one year increase in the log number of suicide, homicide and deaths by road traffic injures from 2010 to 2014 and 2014 to 2017.

\begin{tabular}{|c|c|c|c|c|c|c|}
\hline & Overall & North & Northeast & Southeast & South & Central-West \\
\hline \multicolumn{7}{|l|}{ Mortality } \\
\hline \multicolumn{7}{|l|}{ Suicide } \\
\hline $2010-2014$ & $\begin{array}{c}2.2 \% \\
(\mathrm{p}<0.001)\end{array}$ & $\begin{array}{c}1.5 \% \\
(\mathrm{p}=0.281)\end{array}$ & $\begin{array}{c}2.7 \% \\
(\mathrm{p}<0.001)\end{array}$ & $\begin{array}{c}2.1 \% \\
(\mathrm{p}<0.001)\end{array}$ & $\begin{array}{c}1.9 \% \\
(\mathrm{p}=0.006)\end{array}$ & $\begin{array}{c}2.8 \% \\
(p=0.011)\end{array}$ \\
\hline 2014-2017 & $\begin{array}{c}3.2 \% \\
(\mathrm{p}<0.001)\end{array}$ & $\begin{array}{c}5.1 \% \\
(\mathrm{p}=0.003)\end{array}$ & $\begin{array}{c}5.4 \% \\
(\mathrm{p}<0.001)\end{array}$ & $\begin{array}{c}-0.3 \% \\
(\mathrm{p}=0.684)\end{array}$ & $\begin{array}{c}5.6 \% \\
(\mathrm{p}<0.001)\end{array}$ & $\begin{array}{c}5.1 \% \\
(\mathrm{p}=0.001)\end{array}$ \\
\hline \multicolumn{7}{|l|}{ Homicide } \\
\hline $2010-2014$ & $\begin{array}{c}2.8 \% \\
(\mathrm{p}<0.001)\end{array}$ & $\begin{array}{c}1.1 \% \\
(\mathrm{p}=0.073)\end{array}$ & $\begin{array}{c}5.1 \% \\
(\mathrm{p}<0.001)\end{array}$ & $\begin{array}{c}1.3 \% \\
(\mathrm{p}<0.001)\end{array}$ & $\begin{array}{c}-0.0 \% \\
(\mathrm{p}=0.935)\end{array}$ & $\begin{array}{c}5.8 \% \\
(p<0.001)\end{array}$ \\
\hline 2014-2017 & $\begin{array}{c}0.7 \% \\
(\mathrm{p}=0.004)\end{array}$ & $\begin{array}{c}8.5 \% \\
(p<0.001)\end{array}$ & $\begin{array}{c}4.7 \% \\
(\mathrm{p}<0.001)\end{array}$ & $\begin{array}{c}-5.8 \% \\
(p<0.001)\end{array}$ & $\begin{array}{c}2.0 \% \\
(p=0.003)\end{array}$ & $\begin{array}{c}-3.9 \% \\
(p<0.001)\end{array}$ \\
\hline \multicolumn{7}{|c|}{ Road traffic injuries } \\
\hline 2010-2014 & $\begin{array}{c}-0.6 \% \\
(p=0.001)\end{array}$ & $\begin{array}{c}1.5 \% \\
(\mathrm{p}=0.011)\end{array}$ & $\begin{array}{c}1.8 \% \\
(\mathrm{p}<0.001)\end{array}$ & $\begin{array}{c}-2.0 \% \\
(\mathrm{p}<0.001)\end{array}$ & $\begin{array}{c}-3.1 \% \\
(p<0.001)\end{array}$ & $\begin{array}{c}-0.1 \% \\
(p=0.798)\end{array}$ \\
\hline 2014-2017 & $\begin{array}{c}-8.1 \% \\
(p<0.001)\end{array}$ & $\begin{array}{c}-5.4 \% \\
(\mathrm{p}<0.001)\end{array}$ & $\begin{array}{c}-7.0 \% \\
(p<0.001)\end{array}$ & $\begin{array}{c}-10.6 \% \\
(p<0.001)\end{array}$ & $\begin{array}{c}-6.0 \% \\
(\mathrm{p}<0.001)\end{array}$ & $\begin{array}{c}-9.6 \% \\
(p<0.001)\end{array}$ \\
\hline
\end{tabular}

${ }^{1}$ Coeficients are expressed in percentages and also mean $\operatorname{coef}^{\star} 10^{2}$. For incidence rate ratios (IRR) one should use $\exp ($ coef).

crease in the Central-West region are probably the reason for this overall slowing down process, as in the other three Brazilian regions the homicide rates continue to increase. The Southeast region had a growth of $1.3 \%$ for the period of 2010 to 2014 , but a reduction of $5.8 \%$ from 2014 to 2017, whereas the North had a growth of $1.1 \%$ and $8.5 \%$ in homicide rate in the same periods. The Northeast region had a growth of $4.7 \%$ in the second period analysed (Table 1).

Poverty and inequality had both been associated with violent crimes $^{24}$, in Brazil homicide have been related to property crimes and illicit drugs trafficking ${ }^{22}$. A recently published study showed that homicide in Brazil was reduced with increased coverage of the Brazilian cash transfer programme $^{10}$, which indicates that the socioeconomic situation influences the homicide rates in Brazil. Therefore, when austerity measures treat the welfare state it can possibly influence the homicide rates.

\section{Road traffic injuries}

Traffic injuries are important causes of death globally. In 2002 it was the ninth cause of death and it is known to be a worse problem in developing countries ${ }^{25}$. The relationship between traffic fatalities and economic crisis are less known. A paper investigating the Italian case after the 2008 economic crisis reported a reduction in the road traffic fatalities, however, they interpreted the finding as resulting from government measures towards better traffic law-making in the country ${ }^{26}$.

We found a steady reduction in mortality by road traffic injuries in all Brazilian regions from 2014 to 2017 (Figure 1). Before this period, from 2010 to 2014 the mortality by road traffic injuries seemed to be stable, but increasing among the poorest municipalities (Figure 2).

One of the limitations of the present study is the short period analysed, therefore the results found need to be interpreted cautiously. We would need a longer period since the crisis and the austerity policies have started to infer firm conclusions. The main strength of this study is that it gives an overview of many important outcomes that might be related to the crisis and the austerity policies in Brazil. The hypothesis brought can be tested by further investigations using statistical inferential analysis.

\section{Implications}

The possible impact of austerity policies on health should be taken into consideration during policy and law-making. These measures can possibly change the direction of important indicators in health, as mortality due to external causes. However, it should be noticed that this is a descriptive study, whose findings cannot be inter- 
preted as causal. It serves as indication of trends that happened during a period of financial crisis.

\section{Final remarks}

Although this is a descriptive study, we showed that mortality rate increase by external causes was more prominent among the poorer regions (North and Northeast) while the richest regions in Brazil are showing a steady decrease in deaths by road traffic injuries. These results suggest that the crisis in Brazil contributed to the intensifica- tion of the inequalities in an already very unequal country. The homicide rate in Brazil has been relatively stable in the last decade and the lack of equality across regions is warring.

The austerity policies in the Brazilian economic crisis seem to have influenced the dynamics of mortality due to external causes in Brazil, with a stronger burden in the poorest regions. Policy makers from the underperforming regions could evaluate what helped richer regions succeed, the Federal government should mediate and guide regional leaders towards informed decisions based on scientific evidence.

\section{Collaborations}

DB Machado conceptualized the study and worked on the analysis, interpretation of the data, wrote the first draft and approved the final version of the manuscript. JM Pescarini and LFS Castro-de-Araujo worked on the analysis, interpretation of the data, wrote the first draft and approved the final version of the manuscript. ML Barreto worked on the interpretation of the data, supervised and approved the final version of the manuscript. 


\section{References}

1. Nagy S. Economic Crisis in Brazil: Its Roots, Causes and Scenarios [Internet]. Budapest: Institute for Foreign Affairs and Trade; 2018. [acessado 2019 Jan 24]. Disponível em: http://real.mtak.hu/80706/1/04_KKI_ Studies_BRA_Nagy_Ricz_20180208_u.pdf

2. Vieira FS. Crise econômica, austeridade fiscal e saúde: Que lições podem ser aprendidas? [Internet]. Brasília: IPEA; 2016 (Nota Técnica no 26). [acessado 2019 Jan 24]. Disponível em: http://www.ipea.gov.br/portal/images/stories/PDFs/nota_tecnica/160822_nt_26_disoc. pdf

3. Blyth M. Austerity: The History of a Dangerous Idea. Oxford: Oxford University Press; 2013.

4. Stuckler D, Basu S. The Body Economic: Why Austerity Kills: Recessions, Budget Battles, and the Politics of Life and Death. New York: Basic Books; 2013.

5. Barreto ML. Austerity arrived in Latin-America: What we must learn from the recent European experience on studying its effects on health? Salud Colectiva 2018; 14(4):681-684.

6. Rasella D, Basu S, Hone T, Paes-Sousa R, Ocké-Reis CO, Millett C. Child morbidity and mortality associated with alternative policy responses to the economic crisis in Brazil: A nationwide microsimulation study. PLoS Med 2018; 15(5):e1002570.

7. Campello T. Faces da desigualdade no Brasil: um olhar sobre os que ficam para trás [livro na Internet]. Brasília: Conselho Latino-Americano de Ciências Sociais; 2017. [acessado 2019 Jan 24]. Disponível em: http://flacso.org.br/files/2017/11/faces_da_desigualdade_no_brasil_online_2018.pdf

8. Machado DB, Rasella D, Santos DN. Impact of Income Inequality and Other Social Determinants on Suicide Rate in Brazil. PLoS One 2015; 10(4):e0124934.

9. Alves FJO, Machado DB, Barreto ML. Effect of the Brazilian cash transfer programme on suicide rates: a longitudinal analysis of the Brazilian municipalities. Soc Psychiatry Psychiatr Epidemiol 2018; 54(4):599606.

10. Machado DB, Rodrigues LC, Rasella D, Barreto ML, Araya R. Conditional cash transfer programme: Impact on homicide rates and hospitalisations from violence in Brazil. PLoS One 2018; 13(12):e0208925.

11. Labonté R, Stuckler D. The rise of neoliberalism: how bad economics imperils health and what to do about it. J Epidemiol Community Health 2016; 70(3):312-318.

12. World Health Organization (WHO). International Statistical Classification of Diseases and Related Health Problems: 10th Revision ICD-10. 5a ed. Geneva: WHO; 2016.

13. Mello-Santos C, Bertolote JM, Wang Y-P. Epidemiology of suicide in Brazil (1980-2000): characterization of age and gender rates of suicide. Braz J Psychiatry 2005; 27(2):131-134.

14. Machado DB, Santos DN. Suicide in Brazil, from 2000 to 2012. Jornal Brasileiro de Psiquiatria 2015; 64(1):45-54.

15. Machado DB, Alves FJ, Rasella D, Rodrigues L, Araya R. Impact of the new mental health services on rates of suicide and hospitalisations by attempted suicide, psychiatric problems, and alcohol problems in Brazil. Administration and Policy in Mental Health and Mental Health Services Research 2018; 45(3):381-391.
16. Houle JN, Light MT. The harder they fall? Sex and race/ethnic specific suicide rates in the U.S. foreclosure crisis. Soc Sci Med 2017; 180:114-124.

17. Tanji F, Kakizaki M, Sugawara Y, Watanabe I, Nakaya N, Minami Y, Fukao A, Tsuji I. Personality and suicide risk: the impact of economic crisis in Japan. Psychol Med 2015; 45(3):559-573.

18. Isabel RP, Miguel RB, Antonio RG, Oscar MG. Economic crisis and suicides in Spain. Socio-demographic and regional variability. Eur J Health Econ 2017; 18(3):313-320.

19. Benioudakis ES, Lykiardopoulos V, Georgiou V, Archontaki MD, Tsourounaki A, Botonaki G, Batzou A, Symiakos T, Seliniotaki T, Armagos A, Pentari A, Moiradorakis K, Darakis E, Melissari-Tzanakaki M. Suicide Attempts and Their Interrelation With the Economic Crisis in Chania, Greece: A Time-Series Analysis of the Period 2008-2015. Prim Care Companion CNS Disord 2017; 19(1):16m02035.

20. Cerqueira D, Lima RC, Bueno S, Neme C, Ferreira H, Coelho D, Alves PP, Pinheiro M, Astolfi R, Marques D, Reis M, Merian F. Violence Atlas [livro na Internet]. Brasília: IPEA; 2018. [acessado 2019 Jan 27]. Disponível em: http://www.forumseguranca.org.br/ wp-content/uploads/2018/06/FBSP_Atlas_da_Violencia_2018_Relatorio.pdf

21. Brasil. Ministério da Saúde (MS). Secretaria de Gestão Estratégica e Participativa. Suicide death among black adolescents and youth from 2012 to 2016 [Internet]. Brasília: MS; 2018. [acessado 2019 Jan 28]. Disponível em: http://bvsms.saude.gov.br/bvs/publicacoes/obitos_suicidio_adolescentes_negros_2012_2016.pdf

22. Reichenheim ME, Souza ER, Moraes CL, Jorge MHPM, Silva CMFP, Minayo MCS. Violence and injuries in Brazil: the effect, progress made, and challenges ahead. Lancet 2011; 377(9781):1962-1975.

23. Butchart A, Mikton C. Global status report on violence prevention 2014. Geneva: WHO; 2014.

24. Hsieh CC, Pugh MD. Poverty, Income Inequality, and Violent Crime: A Meta-Analysis of Recent Aggregate Data Studies. Crim Justice Rev 1993; 18(2):182-202.

25. Nantulya VM, Reich MR. The neglected epidemic: road traffic injuries in developing countries. BMJ 2002; 324(7346):1139-1141.

26. Mattei G, Ferrari S, Pingani L, Rigatelli M. Short-term effects of the 2008 Great Recession on the health of the Italian population: an ecological study. Soc Psychiatry Psychiatr Epidemiol 2014; 49(6):851-858.

Artigo apresentado em 30/01/2019

Aprovado em 12/07/2019

Versão final apresentada em 29/08/2019 
